DOI 10.14746/ssp.2019.2.11

José Luis Orella Martínez

CEU San Pablo University

ORCID: 0000-0003-2727-5955

Joanna RAK

Adam Mickiewicz University in Poznań

ORCID: 0000-0002-0505-3684

\title{
Formation of populism in Spain: towards the explanatory framework of the 15-M Movement mindset ${ }^{1}$
}

\begin{abstract}
This article aims to identify the major cores of the 15-M Movement mindset and explain how particular historical factors shaped it. The research problems are to identify the types of relations the movement established between the people and the ruling elites in its political manifestos, and the sources of these discursively created relations. The research field encompasses the content of political manifestos published between the Spanish general election on March 9, 2008 and immediately after the demonstrations held on May 15, 2011. To solve these problems, the research applies source analysis of the political manifestos. These are: (1) The Manifesto of ;Democracia Real YA!; (2) The Manifesto of the Puerta del Sol Camp, and (3) The Manifesto "May 68 in Spain." The research uses the technique of relational qualitative content analysis to determine the relations between the semantic fields of the major categories of populism, 'the people' and 'the elites,' as well as to identify the meanings formed by their co-occurrence. The tool used is a content analysis instruction whose major assumption is to identify all the attempts to create images of 'the people,' 'the elites,' and relations between them.
\end{abstract}

Key words: Spain, anti-austerity movement, contentious politics, populism, political manifesto

\section{Introduction: literature review and methodological assumptions for the research}

$\mathbf{O}$ n May 15, 2011, Spaniards took to the streets to manifest their general opposition to the ruling elites before the upcoming local and

${ }^{1}$ This research paper is a result of the research project The Culture of Political Violence Dynamics of Anti-austerity Movements in Europe. It was financially supported by the National Science Centre, Poland [grant number 2016/23/D/HS5/00192]. 
regional elections scheduled for May 22. These demonstrations gave rise to one of the most aggressive and the largest anti-austerity movements in the Eurozone (Rak, 2018a; 2018b), the 15-M Movement (Spanish: Movimiento 15-M), also known as the movement of 15 May (15-M), Take the Square, the Indignados Movement, the Spanish Indignados, the \#spanishrevolution, and just los indignados (the outraged). Apart from the high level of personal delegitimization of the ruling elite as the immediate cause of political mobilization (Castañeda, 2012, p. 309), the extensive body of literature mentions the following motives: the 2008 financial crisis (Portos García, 2016, p. 181), capitalism in general (della Porta, 2015, p. 29), high unemployment rates (Flesher Fominaya, 2015b, p. 465), the two-party system in Spain (Vázquez, Lois, 2019, p. 1), the political system - quality of democracy (Miley, 2017, p. 264), the level of popular participation in decision-making, the low level of freedom of expression (Gerbaudo, 2017, p. 36), political corruption (della Porta, 2015, p. 28), violations of human rights (Palomo, 2016, p. 925), austerity-based reductions to welfare programs (Berglund, 2018), pensions, health, and social care (Ornellas et al., 2017, p. 535), and education (Zamponi, Fernández González, 2017, p. 64), the low level of work and housing conditions (Flesher Fominaya, 2015a, p. 142; 2015b, p. 465), demonstrations which began in Iceland in 2008 and then spread across the Middle East, North Africa, and Europe (della Porta, 2015, p. 28), Stéphane Hessel's book Indignez-vous! (Time for Outrage!) (Martín-Estudillo, 2014), and the social activity of the NEET-troubled (NEET - Not in Education, Employment, or Training) or lost generation (Lidan, 2013, p. 367). Although these works shed considerable light on the nature of the political mobilization, the causes of contentious performances and demands, they tell little about the motives' contribution to the 15-M Movement mindset.

In turn, qualitative studies of the Spanish anti-austerity movement's political thought and discourse offer mostly descriptive and exploratory approaches to their mindset. Nevertheless, some researchers delve analytically into the semantic structures distributed and redistributed by activists, and thus allow us to identify and classify the movement (Kioupkiolis, 2016, p. 99). According to recent research, the discourse created by the Spanish Indignados, especially their diagnostic and prognostic components, as well as the process of collective identity construction meet the essential criteria of populism (Casero-Ripollés, Sintes-Olivella, Franch, 2017, p. 986; Aslanidis, 2016, p. 310; Monterde et al., 2015, p. 946; Errejón, 2015, p. 152; Galais, 2014, p. 334). The first criterion is the mo- 
vement's attempt to politicize civic identity into a collective identity of a moral people that encompasses an overwhelming majority, against which are the corrupt forces of a small minority of political elites (Aslanidis, 2016, p. 310). Second, the 15-M Movement's framing diagnoses elites as having corroded the main pillars of democracy (popular sovereignty and majority rule) to deprive the people of social, civil and political rights, and serve their narrow particularistic interests (Aslanidis, 2016, p. 310). Third, the movement's calls for action contain wake-up appeals, a commitment to toppling the ruling elites and restoring sovereignty through the grassroots mobilization of the people (Aslanidis, 2016, p. 310). Although these conclusions make a significant contribution to our knowledge of the 15-M Movement's mindset, they avoid accounting for the nature of the mindset's components and thus providing us with a deeper understating of the phenomenon. This study addresses the need to discover the semantic structures built with the discursive relations between the key concepts of populism, 'the people' and 'the elite' (Sengul, 2019, p. 6; Alimi, Demetriou, Bosi, 2015, p. 7).

This article strives to fill the gaps found in the specialist literature on the Spanish Indignados. It aims to identify the major cores of the 15-M Movement mindset and account for how particular historical factors shaped it. The research problems which structure the analysis are of exploratory and explanatory nature. The former focuses on what types of relations between the people and the ruling elites the movement established in their political manifestos. The latter deals with the question of what the sources of these discursively created relations were. It aims to discover the determinants of the images.

The research field encompasses the content of political manifestos published between the 2008 Spanish general election (March 9, 2008) and immediately after the occurrence of the Spanish anti-austerity movement (May 15, 2011). Importantly, as a result of the election, José Luis Rodríguez Zapatero was sworn in as Prime Minister for a second term, when the Spanish economy started showing signs of fatigue and economic slowdown after ten years of growth. In 2011, relative deprivation in society hit a peak and triggered a great social mobilization. The caesurae determine this period of Spanish history, which abounded in events considered the trigger points for the creation of the 15-M Movement. The events are selected using process trace procedures, and introduced to account for the roots of the Spanish Indignados mindset. 
For the sake of clarity, this article understands social movements as conscious, collective, and organized efforts at social change (Edwards, 2014, p. 4); here, at the abandonment of austerity measures, removing their results, and providing or restoring social well-being (Páez et al., 2013 , p. 21). They exist over a span of time by coming into conflict with a powerful opponent (Edwards, 2014, p. 4; Diani, 1992, p. 2); here, those who were blamed for the social consequences of austerity policies, mainly the European Union, political and economic elites. Movement participants work together to carry out, resist, or undo social change (Bosi, Giugni, Uba, 2016, p. 3). They co-create and share a collective identity, and actively strive for a change in their social situation often by using protest (Edwards, 2014, pp. 4, 5; Polletta, Jasper, 2001, p. 283).

The method employed to solve the research problems is the source analysis of the political manifestos released directly before the movement's institutionalization and after the Spanish Indignados social mobilization. These are: (1) The Manifesto of ;Democracia Real YA! (DRY) (Real Democracy NOW!), also known as Plataforma Democracia Real Ya! (Real Democracy NOW Platform!), the grassroots organization whose action sparked the May 15 demonstrations, published in March 2011; (2) The Manifesto of the Puerta del Sol Camp released on May 20, 2011 during the first demonstrations of the newly-created 15-M Movement, and (3) The Manifesto "May 68 in Spain" published on February 9, 2011 by the representatives of young Spaniards. They are important for the research as the pre-institutional and the fledgling movement's expression of collective identity, and the demands which pulled further supporters in and aligned them against the ruling elites. The research uses the technique of relational qualitative content analysis to determine the relations between the semantic fields of the major categories of populism 'the people' and 'the elites' and identify the meanings formed by their co-occurrence. The tool used is a content analysis instruction whose major assumption is to identify all the attempts to create the images of 'the people,' 'the elites,' and the relations between them.

The next part of the article traces the history of the relations between the ruled and the rulers in Spain from 2008 to 2011 which are referred to in the Spanish Indignados political manifestos. They are considered the trigger points for the Indignados' outrage. Then, the concern moves on towards the discursive creations of these relations, since the research accounts for the meanings given to them by social activists. 


\section{The trigger points for the outrage}

The overview of the trigger points begins with the event considered the opening caesura for the research field, the election in Spain. José Luis Rodríguez Zapatero from Partido Socialista Obrero Español, PSOE (the Spanish Socialist Workers' Party) won his second term in March 2008, followed very close by the Partido Popular (PP) (People's Party) of Mariano Rajoy. Then, after a decade of prosperity, the 2008 economic crisis influenced the Spanish economy, which started showing an economic slowdown (Wigger, 2018, p. 32; Taibo, 2013, p. 133). Construction prices collapsed and the housing bubble burst. The world of construction, linked to tourism which was one of the main engines of the Spanish economy, stopped being self-sufficient. The high demand for unskilled labor began the opening of the country to immigration processes. The popular government of José María Aznar reinforced the phenomenon so as to rejuvenate the Spanish population and lower labor costs with an abundance of workers. The collapse of this important sector triggered high unemployment figures and finally caused a great financial crisis in Spain. Spaniards were trapped in mortgages impossible to pay due to recent unemployment. Savings banks and non-profit social financial entities existed, but were controlled by autonomous governments and municipalities. They were indebted to prohibitive levels in favor of the policies of these entities. The disappearance of the savings banks, along with the collapse of the construction sector revealed the main element of illegal financing of the main political parties with parliamentary representation and governmental responsibility. The political corruption that affected hundreds of its leaders inspired the calls for financial transparency and change of the ruling elites (Charnock, Purcell, Ribera-Fumaz, 2012, p. 3). According to the State's Attorney General, Cándido Conde-Pumpido, in November 2009 a total of 730 cases against public officials for corruption were being processed. The main parties with the ability to form a government, the PSOE and PP, accounted at that moment for 464 of the total of the cases (264 against the PSOE and 200 against the PP).

The most serious consequences of these factors for Spain were the increase in inflation, which exceeded $4 \%$, the increase of oil prices and basic foodstuffs, the increase of unemployment, and sharp drops in industrial production, VAT collection, and credit granted. Due to the deficit of $11.2 \%$ and unemployment of $20.1 \%$, which affected 4.6 million people, 
the executive authorities decided to change economic policy to avoid the intervention of the European Commission, the European Central Bank, and the International Monetary Fund, which had happened in Greece, Portugal and Ireland (EPA, 2013).

The government tried to reduce the extent of unemployment and deal with the collapse of confidence in politicians with labor reforms that increased job insecurity and poverty in large sectors of the middle and lower classes of Spanish society. The measures approved by the socialist government of Rodríguez Zapatero meant a reduction of $€ 15$ billion, the freezing of pensions, reductions in the salaries of public employees and labor reforms in favor of measures of labor flexibility (despidos baratos - cheap dismissals) that led to the general strike of September 29, 2010 against the measures adopted by the socialist government, and that was supported by the unions: Comisiones Obreras (CCOO) (the Workers' Commissions), Unión General de Trabajadores (UGT) (the General Union of Workers), Unión Sindical Obrera (USO) (Workers' Trade Union), and Confederación General del Trabajo (CGT) (General Confederation of Labor). Public employees became one of the most sensitive social elements, because of the loss of their purchasing power after 2010. This was the last year when their salaries increased. From then on, the austerity measures imposed by the government focused first on reducing their salaries by $5 \%$, and then freezing them. In 2012, the government implemented an extra measure, the non-payment of extra Christmas benefits (equivalent to $7 \%$ of their annual salary).

The next visible consequence of the crisis was evictions (Barbero, 2015, p. 271; García-Lamarca, 2017, p. 38). From 2007 to the first half of 2012, there were 417000 repossessions. As a result of them, 203808 individuals or families lost their homes. In response, the grassroots organization Plataforma de Afectados por la Hipoteca (PAH) (Platform for People Affected by Mortgages) was formed in 2009 in Barcelona, based on Movimiento por una Vivienda Digna (Movement for Dignified Housing), founded in 2003, which had the support of groups linked to the CGT, CCOO and Izquierda. The PAH held campaigns for housing rights and staged demonstrations in front of homes to stop the evictions (Gonzalez, Martinez, Barranco, 2018, p. 88). These experiences highly inspired the 15-M Movement mindset, which is revealed in how they shaped the discursive establishment of the relations between 'the people' and 'the elites' in their political manifestos. 


\section{The outrage of the 2011 Spanish populists}

The first analyzed manifesto is by the DRY, the grassroots organization set up in March 2011 in Spain. Its political activity triggered the demonstrations of May 15 and created the basis for the new movement (Mangado, 2015, p. 52). The DRY's manifesto introduces the collective self-identity and political demands (¡Democracia Real YA!, 2011). The activists point out that they are ordinary people, and encourage potential supporters by drawing similarities between 'we' and 'you.' At the beginning of the manifesto, we read: "We are like you: people, who get up every morning to study, work or find a job, people who have family and friends. People, who work hard every day to provide a better future for those around us" (¡Democracia Real YA!, 2011). As the organization assumes, while its participants differ in political (progressive, conservative, ideology-driven, apolitical) and religious views, they share anger about the political, economic, and social outlook which they see around them: corruption among politicians, businessmen and bankers, leaving them helpless, without a voice (¡Democracia Real YA!, 2011). So, the DRY is the overtly catch-all movement, and this pattern of social inclusion typifies the Spanish Indignados.

The organization opposes this political situation, and the fact that it has become normal. They compare it to daily suffering, without hope, and call for a different future. According to the manifesto: "But if we join forces, we can change it. It's time to change things, time to build a better society together" (¡Democracia Real YA!, 2011). On the one hand, the document introduces the means of change which are highly general, and thus far from a ready program. On the other, the statement proclaims that the people who support the movement are a powerful social force capable of improving the quality of social life.

The manifesto puts forward an array of demands. The list begins with the priorities of advanced societies. These are equality, progress, solidarity, freedom of culture, sustainability and development, welfare and people's happiness. In addition, Spanish society should observe inalienable rights: the right to housing, employment, culture, health, education, political participation, unfettered personal development, and consumer rights for a healthy and happy life. The organization delegitimizes the ruling elites by arguing that the government and economic system does not take care of these rights, and hinders human progress (¡Democracia Real YA!, 2011). Ensuring these rights and human progress in order to shape society 
generate a sharp contrast between the advanced society represented by the people, and the backward world ruled by the Spanish political and economic elites.

DRY shows its idea of the ideal political regime for Spain. In their opinion, "democracy belongs to the people (demos $=$ people, krátos = government) which means that government is made of every one of us" (¡Democracia Real YA!, 2011). They contrast it with the current situation in Spain where "most of the political class does not even listen to us" (¡Democracia Real YA!, 2011). In addition, they draw the difference between the expected and the existing ways of performing political roles by their representatives: "Politicians should be bringing our voice to the institutions, facilitating the political participation of citizens through direct channels that provide the greatest benefit to the wider society, not to get rich and prosper at our expense, attending only to the dictatorship of major economic powers and holding them in power through a bipartisanship headed by the immovable acronym PP \& PSOE” ( Democracia Real YA!, 2011). The next demand also reveals the need for the change of political elites: "Lust for power and its accumulation in only a few; create inequality, tension, and injustice, which leads to violence, which we reject. The obsolete and unnatural economic model fuels the social machinery in a growing spiral that consumes itself by enriching a few and sends into poverty the rest. Until the collapse” (¡Democracia Real YA!, 2011). The ruling elites are blamed for inciting political and economic violence against the people.

The next critical remarks on how the ruling elites perform political roles concern their goals. In this case, they are equated with the whole political system: "The will and purpose of the current system is the accumulation of money, not regarding efficiency and the welfare of society. Wasting resources, destroying the planet, creating unemployment and unhappy consumers” (¡Democracia Real YA!, 2011). Therefore, according to social activists, the ruling elites focus on their particularistic objectives, rather than common well-being.

Interestingly, in general, the manifesto is neither an expression of helplessness, nor an acknowledgment of weakness up against a powerful opponent. Aside from one sentence in the opening part of the document, it lacks the statements of oppressed weak people peculiar to populism. Instead, the Spanish Indignados manifest an awareness of their own political potential: "Citizens are the gears of a machine designed to enrich a minority which does not regard our needs. We are anonymous, but wi- 
thout us none of this would exist, because we move the world" ( $i D e m o-$ cracia Real YA!, 2011). The activists express their power against vaguely outlined forces: "If as a society we learn to not trust our future to an abstract economy, which never returns benefits for the most, we can eliminate the abuse that we are all suffering" (iDemocracia Real YA!, 2011). They emphasize the ethical dimension of their protest: "We need an ethical revolution. Instead of placing money above human beings, we shall put it back to our service. We are people, not products. I am not a product of what I buy, why I buy and who I buy from” (¡Democracia Real YA!, 2011). It is a strong collective self-identity which attracts potential supporters thanks to the promise of co-formulation of a powerful movement. The manifesto ends with a kind of confession of political faith: "For all of the above, I am outraged. I think I can change it. I think I can help. I know that together we can. I think I can help. I know that together we

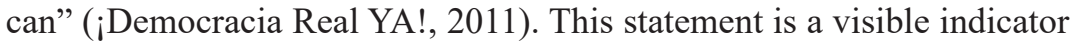
of an attempt to create a political religion, appealing to current and prospective proponents.

On May 20, 2011, the Puerta del Sol camp formulated sixteen demands which have shaped their further argumentation (\#Acampadasol, 2011). ${ }^{2}$ This document contains more specific demands than the DRY's Manifesto. It commences with the demand to change the Electoral Law, so that the lists were open and for a single constituency. Moreover, the obtaining of seats must be proportional to the number of votes (\#Acampadasol, 2011). As the Spanish Indignados assume, they propose a new idea to make the current electoral law fairer, because the system supported by the current ruling elites is unfair. Furthermore, the 15-M Movement holds out for a change of political regime into a participatory and direct democracy in which citizens take an active part. This demand is finished with the expression of the need for popular access to the media, which must be ethical and disseminate only accurate news (\#Acampadasol, 2011). The argumentation indicates that the current ruling political elites fail to meet the movement's expectations connected to their image of a perfect democratic regime. They want to achieve a higher level of participation in decision-making processes.

The Spanish Indignados oppose violations of the law by demanding attention to the basic and fundamental rights included in the Constitution.

${ }^{2}$ The article uses its own translation of the statement originally announced in Spanish. 
They emphasize the right to a decent home, fair credit facilities, free and common access to public health care, and the reinforcement of public, secular education. According to the manifesto, the people are crying out for the true regularization of working conditions and monitoring compliance by the state authorities (\#Acampadasol, 2011). So, the ruling elites infract these rights and support the law, which lets them avoid punishment and preserve the existing situation.

The next demands refer to the unfair taxation imposed by the ruling elite, since the movement expected favorable tax reforms for lower incomes, a reform of inheritance and estate taxes, implementation of the Tobin Tax, which taxes international financial transfers, and the suppression of tax havens. The activists highlight the need for the reform of the working conditions of the political class, so that their wages were abolished. Interestingly, at this point, they mention that the programs and political proposals must become binding, since politicians fail to fulfil their campaign promises. Then, they call for a change in the political elites and condemn their corruption. According to them, the Electoral Law should make it obligatory to present transparent and open lists of those imputed or condemned by corruption (\#Acampadasol, 2011). In sum, they expect the total transparency of the accounts of political parties as a measure to contain political corruption. This demand emphasizes the difference between the corrupt elites and the people.

The Puerta del Sol camp state that plural measures have to be implemented with respect to banking and financial markets. The response to the consequences of austerity policies is the request for the reduction of the power of the IMF and the ECB, the immediate nationalization of all those banking entities that were to be rescued by the state, and strengthening controls over financial entities and operations to avoid possible abuses in any of its forms (\#Acampadasol, 2011). The Spanish Indignados blame the political and economic elites for the consequences of the austerity measures they implemented. As they maintain, the people suffer from the inappropriate decisions of the ruling elite.

The next demands are general and do not directly concern recent historical events. The first relates to religion, and the separation of Church and state, as established in Article 16 of the Constitution. The movement insists on the closure of all nuclear power plants and the promotion of renewable and free energy; recovery of privatized public companies; effective separation of executive, legislative, and judicial authorities; reduction of military spending, immediate closure of arms factories and 
greater control of State security forces and bodies (they declare that, as a pacifist movement, they say 'No to war'); and the recovery of historical memory and the founding principles of the struggle for democracy in Spain (\#Acampadasol, 2011). However, these statements are highly general and serve to bolster the image of a catch-all movement (Errejón, 2011, p. 123). In addition, they strengthen the image of a ruling elite who fail to meet common expectations.

On February 9, 2011, in referring to the French student protests in 1968, the young activists published a manifesto "Mayo del 68 en España" (May 68 in Spain) (Gallego, 2011). ${ }^{3}$ As the manifesto tells us, they "do not want more bipartisanship in Spanish democracy" (Gallego, 2011). Thus, the activists confirm that they do not approve of the current political system. Instead, they propose state pluralism as a measure to put an end to the corruption of politicians and, on the other hand, the commitment of parties to propose candidates whose preparation to manage and exercise their functions and responsibilities is optimal (Gallego, 2011). Spaniards discursively oppose the corrupt political elites that avoid performing their roles in a socially accepted manner. Moreover, the elected politicians must take preventive measures to avoid any future crises. So, the ruled make their representatives responsible for their future well-being.

The Spanish Indignados demand that unions must be free, and they seek the repeal of state aid to them, so that future pacts with the state are in the interest of the workers and cannot be subjugated to any type of government. They consider the creation of companies the real solution for the Spanish economy (Gallego, 2011). Moreover, those who do not have benefits, in the beginning, should not pay taxes of any kind. They reject fraud at the Treasury, embezzlement of public funds or other forms of fraud, considering those who engage in it enemies of the welfare state, whose pillars are free health care and education for all (Gallego, 2011). As they maintain, they aim at promoting the social awareness of the rental of housing by all citizens, and thus promote decent housing at a fair price for all (Gallego, 2011). They manifest the desire to leave the past and concentrate on the future, assuming the utmost respect for the victims of the civil war on both sides, and remembering them as victims of a conflict they should never have been part of (Gallego, 2011). They express their opposition to violence in all its forms from acts of vandalism to terrorist

3 The article presents own translation of the manifesto originally announced in Spanish. 
attacks. The young assume that research, development, and innovation must be one of the fundamental pillars to make Spain competitive. All those actions that involve long-term benefits for society must be supported by government. States and their governments should not be subjugated to banks or multinationals, defending at all times the labor rights of workers (Gallego, 2011). Just like the other documents, this manifesto emphasized the social, political, and economic dimensions of relative deprivation. The types of relations between the ruled and the rulers illustrate the nature of these deprivations.

\section{Conclusions}

In the analyzed manifestos, the Spanish Indignados established thirteen types of relations between 'the people' and 'the ruling elites.' The first type of relation is based on the contrast between ordinary people and the representatives of the political and economic elites. Recent political anger is derived from experience of the political, economic, and social outlook which they see around them: corruption among politicians, businessmen and bankers, leaving them helpless, without a voice, and so bring the people together against the ruling elites.

The second type shows the difference between, on the one side, the people who crave an advanced society based on equality, progress, solidarity, freedom of culture, access to a free, ethical, and trustworthy media, sustainability and development, welfare, fair taxation, people's happiness, the right to housing, employment, culture, health, education, political participation, unfettered personal development, free unions, help for private undertaking, and consumer rights for a healthy and happy life, and, on the other, the government and economic system, which does not take care of these rights and hinders human progress. This relation also has a more radical form, which draws on the assumption that the ruling elites not only avoid taking care of these rights, but also violate them.

Accordingly, in line with the third discursive construction, the movement is the exponent and guard of the basic and fundamental rights included in the Constitution, and wants the people to be provided with the right to a decent home, sees the need for a reform of the Mortgage Law to provide people with a house in case of mortgage default, free and common access to public health care, and reinforcement of public, secular education. 
Fourth, the people suffer from austerity measures and the inappropriate decisions of the ruling elite, while the latter benefit from them. These relations result from blaming the political and economic elites for the socially unpopular austerity measures and their consequences.

Fifth, the context for the fourth type of relation is the Spanish democratic system. On the one hand, the 15-M Movement identifies the people who expect representation and, on the other, a political class which is not able to represent them. In this situation, the ruled demand participation in power, while the ruling elites are focused on meeting rather particularistic needs.

Sixth, the movement proposes a new, fair electoral law, while the ruling elites are those who support the current, unfair law. Seventh, the ruling elites are corrupt, whilst the ruled people condemn corruption. Eighth, the representatives of the movement reject violence, while the rulers incite it by creating inequality, tension, and injustice. Ninth, by referring to social justice, the movement shows the relation between the people who are poor and are getting poorer because of the austerity policies, and the political elites whose wages are unfairly high. The next, tenth type of relation draws on a descriptive approach towards the activities of the people and the ruling elites. Whilst the former group uphold the law, the latter do not obey it.

Eleventh, the Spanish Indignados present themselves as people that want those elected to keep their word. The elites, however, do not fulfil their promises. The twelfth type of relation draws on the manifestation of the awareness of their own potential. The Spanish Indignados present themselves as a powerful political movement that is able to defeat its opponent if it joins forces. The ruling elites are a minority that can be changed. Finally, according to the activists, their political opponents are responsible for the future. The depicted relation draws upon the assumption that government should not let future economic crises happen. The people are to be protected. This relation stems from the fear of the next wave of post-crisis austerity policies that affected their current well-being.

In sum, the paper argues that the semantic fields of all the determined types of relations are historical experience-driven. They generate a coherent image of a political reality structured with 'the people,' represented by the movement, and 'the ruling elites,' blamed for the social consequences of austerity programs. The typology sheds light on the spectrum of semantic creations distributed by the Spanish anti-austerity movement, rather than projecting the perspective of radical holism (Flesher Fominaya, 2010, p. 393; 
Mercado Maldonado, Hernández Oliva, 2010, p. 230; Tejerina, 2010). The Indignados have created a highly diversified collective identity, which does not mean, however, that it is shared by all their participants. Last, but not least, the article contributes to social movement studies by formulating a typology of discursively created relations by the 15-M between themselves and their political opponents. It may thus be used as a theoretical tool to trace how the Indignados' mindset spreads over time and space.

\section{References}

\#Acampadasol (2011), Propuestas aprobadas en la Asamblea de hoy día 20 de mayo de 2011 en ACAMPADA SOL, 20.05.2011, https://madrid.tomalaplaza. net/2011/05/20/propuestas-20-mayo/, 22.01.2019.

¡Democracia Real YA! (2011), Manifesto, 01.03.2011, http://www.democraciarealya. es/manifiesto-comun/manifesto-english/, 22.01.2019.

Alimi E. Y., Demetriou Ch., Bosi L. (2015), The Dynamics of Radicalization. A Relational and Comparative Perspective, Oxford University Press, New York.

Aslanidis P. (2016), Populist social movements of the great recession, "Mobilization: An International Quarterly", vol. 21, no. 3.

Barbero I. (2015), When rights need to be (re) claimed: Austerity measures, neoliberal housing policies and anti-eviction activism in Spain, "Critical Social Policy", vol. 35 , no. 2 .

Berglund O. (2018), Contesting Actually Existing Austerity, "New Political Economy", vol. 23, no. 6 .

Bosi L., Giugni M., Uba K. (2016), The Consequences of Social Movements: Taking Stock and Looking Forward, in: The Consequences of Social Movements, eds. L. Bosi, M. Giugni, K. Uba, Cambridge University Press, Cambridge.

Casero-Ripollés A., Sintes-Olivella M., Franch P. (2017), The populist political communication style in action: Podemos's issues and functions on Twitter during the 2016 Spanish general election, "American Behavioral Scientist", vol. 61, no. 9.

Castañeda E. (2012), The Indignados of Spain: A Precedent to Occupy Wall Street, "Social Movement Studies", vol. 11, nos. 3-4.

Charnock G., Purcell T., Ribera-Fumaz R. (2012), iIndignate!: The 2011 popular protests and the limits to democracy in Spain, "Capital \& Class", vol. 36, no. 1.

della Porta D. (2015), Social Movements in Times of Austerity: Bringing Capitalism Back into Protest Analysis, Polity Press, Cambridge-Malden.

Diani M. (1992), The Concept of Social Movement, "The Sociological Review", vol. 40 , no. 1.

Edwards G. (2014), Social Movements and Protest, Cambridge University Press, Cambridge-New York. 
EPA (2013), Encuesta de la Población Activa (EPA) en el primer trimestre de 2013 en, http://www.ine.es/daco/daco42/daco4211/epa0113.pdf, 08.08.2018.

Errejón Í. (2011), El 15-M como discurso contrahegemónico, "Encrucijadas-Revista Crítica de Ciencias Sociales", vol. 2.

Errejón Í. (2015), We the People El 15-M: ¿ Un populismo indignado?, "ACME: An International Journal for Critical Geographies", vol. 14, no. 1.

Flesher Fominaya C. (2010), Collective Identity in Social Movements: Central Concepts and Debates, "Sociology Compass", vol. 4, no. 6.

Flesher Fominaya C. (2015a), Debunking Spontaneity: Spain's 15-M/Indignados as Autonomous Movement, "Social Movement Studies", vol. 14, no. 2.

Flesher Fominaya C. (2015b), Redefining the Crisis/Redefining Democracy: Mobilising for the Right to Housing in Spain's PAH Movement, "South European Society and Politics", vol. 20, no. 4.

Galais C. (2014), Don't Vote for Them: The Effects of the Spanish Indignant Movement on Attitudes about Voting, "Journal of Elections, Public Opinion and Parties", vol. 24, no. 3.

Gallego P. (2011), Mayo del 68 en España, 09.02.2011, http://manifiestojuventud. blogspot.com/2011/02/del-68-en-espana.html, 22.01.2019.

García-Lamarca M. (2017), From occupying plazas to recuperating housing: Insurgent practices in Spain, "International Journal of Urban and Regional Research", vol. 41, no. 1.

Gerbaudo P. (2017), The indignant citizen: anti-austerity movements in southern Europe and the anti-oligarchic reclaiming of citizenship, "Social Movement Studies", vol. 16, no. 1.

Gonzalez R., Martinez M. A., Barranco O. (2018), Autogestión de equipamientos y espacios urbanos: los centros sociales okupados y autogestionados, in: Movimientos sociales y derecho a la ciudad. Creadores de democracia radical, eds. P. Ibarra, R. Gomá, S. Martí, R. Gonzalez, Icaria, Barcelona.

Kioupkiolis A. (2016), Podemos: the ambiguous promises of left-wing populism in contemporary Spain, "Journal of Political Ideologies", vol. 21, no. 2.

Lidan S. (2013), Global Youth Protests in the Era of Capitalist Economic Crisis, "International Critical Thought", vol. 3, no. 3.

Martín-Estudillo L. (2014), "The Spanish 15-M movement: a consensual dissent?" by Victor Sampedro and Josep Lobera, "Journal of Spanish Cultural Studies", vol. 15 , nos. 1-2.

Mercado Maldonado A., Hernández Oliva A. V. (2010), El proceso de construcción de la identidad colectiva, "Convergencia", vol. 17, no. 53.

Miley T. J. (2017), Austerity politics and constitutional crisis in Spain, "European Politics and Society", vol. 18, no. 2.

Mangado A. R. (2015), Desbordamientos y viaje hacia la izquierda. Prehistoria del movimiento 15M: de\# Nolesvotes a Democracia Real Ya, "Daimon Revista Internacional de Filosofía", vol. 64. 
Monterde A., Calleja-López A., Aguilera M., Barandiaran X. E., Postill J. (2015), Multitudinous identities: a qualitative and network analysis of the $15 \mathrm{M} \mathrm{col}$ lective identity, "Information, Communication \& Society", vol. 18, no. 8.

Ornellas A., Martínez-Román M.-A., Tortosa-Martínez J., Casanova J. L., das Dores Guerreiro M., Engelbrecht L. K. (2017), Neoliberalism and Austerity in Spain, Portugal and South Africa: The Revolution of Older Persons, "Journal of Gerontological Social Work", vol. 60, nos. 6-7.

Páez D., Javaloy F., Wlodarczyk A., Espelt E., Rimé B. (2013), El movimiento 15-M: sus acciones como rituales, compartir social, creencias, valores y emociones, "Revista de Psicología Social", vol. 28, no. 1.

Polletta F., Jasper J. M. (2001), Collective Identity and Social Movements, “Annual Review of Sociology", vol. 27, no. 1.

Palomo E. (2016), Austerity Policies and the Feminist Movement in Spain, "Globalizations", vol. 13, no. 6.

Portos García M. (2016), Taking to the streets in the context of austerity: a chronology of the cycle of protests in Spain, 2007-2015, "Partecipazione e conflitto", vol. 9 .

Rak J. (2018a), The Dynamics of the 15-M Movement's Culture of Political Violence, in: Poland and Spain in Late Modern and Contemporary Civilisation and Culture, eds. M. Mizerska-Wrotkowska, J. L. Orella Martínez, Schedas, Madrid.

Rak J. (2018b), Theorizing Cultures of Political Violence in Times of Austerity: Studying Social Movements in Comparative Perspective, Routledge, London-New York.

Sengul K. (2019), Populism, democracy, political style and post-truth: issues for communication research, "Communication Research and Practice", https://doi.or g/10.1080/22041451.2019.1561399, 23.01.2019.

Taibo C. (2013), The Spanish indignados: A movement with two souls, "European Urban and Regional Studies", vol. 20, no. 1.

Tejerina B. (2010), La sociedad imaginada: movimientos sociales y cambio cultural en España, Trotta, Madrid.

Vázquez A., Lois D. (2019), More than ideology: perceived unfairness differentiates supporters of a new anti-austerity party from supporters of traditional left-wing parties/Más que ideología: la injusticia percibida diferencia a los simpatizantes de un nuevo partido antiausteridad de los simpatizantes de los partidos tradicionales de izquierda, "Revista de Psicología Social/International Journal of Social Psychology", https://doi.org/10.1080/02134748. 2018.1537651, 21.01.2019.

Wigger A. (2018), From dissent to resistance: Locating patterns of horizontalist selfmanagement crisis responses in Spain, "Comparative European Politics", vol. 16 , no. 1 .

Zamponi L., Fernández González J. (2017), Dissenting youth: how student and youth struggles helped shape anti-austerity mobilisations in Southern Europe, "Social Movement Studies”, vol. 16, no. 1. 


\section{Formowanie się populizmu w Hiszpanii: model eksplanacyjny sposobu myślenia Ruchu M-15}

\section{Streszczenie}

Celem artykułu jest zidentyfikowanie głównych elementów sposobu myślenia reprezentowanego przez Ruch M-15 i wyjaśnienie jak konkretne wydarzenia historyczne zainspirowały jego zasoby semantyczne. Problemy badawcze to: jakie typy relacji pomiędzy ludem a elitami rządzącymi zostały przedstawione w manifestach politycznych i jakie były źródła tych dyskursywnych kreacji. Pole badawcze obejmuje treść manifestów ogłoszonych pomiędzy wyborami z 9 marca 2008 w Hiszpanii a bezpośrednio po demonstracjach zorganizowanych 15 maja 2011. Do rozwiązania problemów wykorzystano metodę analizy źródeł, manifestów politycznych. Przeanalizowano: (1) Manifest ¡Democracia Real YA!; (2) Manifest Puerta del Sol Camp, oraz (3) Manifest "Maj 68 w Hiszpanii". Zastosowano również technikę relacyjnej jakościowej analizy zawartości, aby ustalić typy relacji pomiędzy polami semantycznymi głównych kategorii populizmu "ludu" i "elit", a także znaczenia wynikające $\mathrm{z}$ ich współwystępowania. Narzędziem użytym w badaniu jest instrukcja do analizy zawartości dotycząca przeszukiwania manifestów sformułowana na podstawie założenia o dążeniu do wyszczególnienia wszystkich prób dyskursywnych kreacji „ludu”, „elit” oraz relacji pomiędzy nimi.

Słowa kluczowe: Hiszpania, ruch antyoszczędnościowy, kontestacja polityczna, populizm, manifest polityczny 
